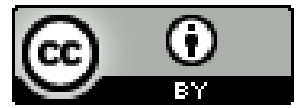

\title{
"ESTANDO EU EM PERFEITO JUÍZO, FAÇO MEU TESTAMENTO": REVELAÇÕES TESTAMENTÁRIAS DE AFRICANOS NO RECIFE OITOCENTISTA
}

\begin{abstract}
José Bento Rosa da Silval
Resumo: Neste artigo investigamos dois testamentos feitos no século XIX, na freguesia (hoje bairro) do Recife, por africanos que passaram pela experiência do cativeiro e posteriormente conquistaram a liberdade. Um deles, de um senhor, solteiro, e que tinha uma filha com a qual vivia desde a mais tenra idade; o outro, de uma viúva que não tivera filhos. Estes testamentos nos revelam um pouco da trajetória destes dois africanos, tais como: o círculo de amizade, a crença, a concepção de mundo, o local onde moravam. Portanto os testamentos revelam aspectos da vida, para além da hora da morte.
\end{abstract}

Palavras-chave: Testamento, africanos, Recife.

\section{"BEING IN MY RIGHT MIND, I MAKE MY WILL": TESTAMENTARY REVELATIONS OF AFRICANS IN 18TH-CENTURY RECIFE.}

\begin{abstract}
In this article we investigate two wills made in the nineteenth century, in the parish (now neighborhood) of Recife, by Africans who went through the experience of captivity and later conquered freedom. One of them, of a gentleman, single, and who had a daughter with whom he lived from an early age; the other, of a widow who had no children. These wills reveal to us a little of the trajectory of these two Africans, such as: the circle of friendship, the belief, the conception of the world, the place where they lived. Therefore the wills reveal aspects of life beyond the hour of death.
\end{abstract}

Keywords: Testament, Africans, Recife.

$$
\begin{aligned}
& \text { "ESTANDO EN MI SANO JUICIO, HAGO MI VOLUNTAD": } \\
& \text { REVELACIONES TESTAMENTARIAS DE AFRICANOS EN RECIFEFE DEL } \\
& \text { SIGLO XVIII. }
\end{aligned}
$$

\footnotetext{
${ }^{1}$ Possui graduação em História pela Fundação do Pólo Regional do Vale do Itajaí (1985), mestrado em História pela Pontifícia Universidade Católica de São Paulo (1PUS-SP. 994) e doutorado em História pela Universidade Federal de Pernambuco (UFPE-2001). Atualmente é professor do programa de pós-graduação em História na UFPE. Membro fundador do NEAB-UFPE. Vinculado ao Centro De Estudos Africanos da Universidade do Porto (Portugal- 2002/2016) como investigador doutorado. Estágio pós-doutoral na Université Jean Jures - Mirail I [Toulouse- 2014-2015]. Membro do Núcleo de Estudos de Identidades e Relações Interétnicas da Universidade Federal de Santa Catarina. E-mail: bentorosa.ebano@gmail.com
}

Revista da ABPN • v. 12, n. Ed. Especial - Caderno Temático: "Africanos, escravizados, libertos biografias, imagens e experiências atlânticas” • agosto de 2020, p. 784-806 
Resumen: En este artículo investigamos dos voluntades hechas en el siglo XIX, en la parroquia (ahora barrio) de Recife, por africanos que pasaron por la experiencia del cautiverio y más tarde conquistaron la libertad. Uno de ellos, de un caballero, soltero, y que tuvo una hija con la que vivió desde una edad temprana; la otra, de una viuda que no tenía hijos. Estas voluntades nos revelan un poco de la trayectoria de estos dos africanos, tales como: el círculo de la amistad, la creencia, la concepción del mundo, el lugar donde vivieron. Por lo tanto, las voluntades revelan aspectos de la vida más allá de la hora de la muerte.

Palabras clave: Voluntades, africanos, Recife.

\section{"ÉTANT DANS MON BON ESPRIT, JE FAIS MA VOLONTÉ": RÉVÉLATIONS TESTAMENTAIRES D'AFRICAINS DANS RECIFE DU XVIIIE SIÈCLE.}

Résumé: Dans cet article, nous enquêtons sur deux testaments faits au XIXe siècle, dans la paroisse (aujourd'hui quartier) de Recife, par des Africains qui ont vécu l'expérience de la captivité et qui ont ensuite conquis la liberté. L'un d'eux, d'un gentleman, célibataire, et qui avait une fille avec qui il a vécu dès son plus jeune âge; l'autre, d'une veuve qui n'avait pas d'enfants. Ces volontés nous révèlent un peu de la trajectoire de ces deux Africains, tels que: le cercle de l'amitié, la croyance, la conception du monde, le lieu où ils ont vécu. Par conséquent, les testaments révèlent des aspects de la vie au-delà de l'heure de la mort.

Mots-clés: Testament, Africains, Recife.

\section{AS ESCRITAS DOS TESTAMENTOS: À GUISA DE INTRODUÇÃO}

De modo geral, os testamentos no Brasil Colônia e Império iniciavam-se da maneira seguinte: "Em nome de Deus, Amém. Estando eu, fulano de tal em perfeito juízo, faço meu testamento". Isso porque, caso não estivesse em pleno juízo, o testamento podia ser considerado nulo, pois, segundo as Ordenações Filipinas, nem todas as pessoas podiam fazer testamentos; entre eles os loucos, mentecaptos ou idiotas (FURTADO, 2009, p. 96-97).

A sensação que geralmente temos, quando se fala em fazer o testamento, é de alguém que está no leito de morte, esperando a derradeira hora, mas nem sempre é assim que acontece, pois há os que, visando dar segurança aos descendentes, resolvem em

Revista da ABPN • v. 12, n. Ed. Especial - Caderno Temático: "Africanos, escravizados, libertos biografias, imagens e experiências atlânticas" • agosto de 2020 , 
determinado momento fazer por escrito o seu legado, destinando a cada um o que entende que deva merecer.

No caso deste artigo, investigamos dois testamentos feitos no século XIX, na freguesia (hoje bairro) do Recife, por africanos que passaram pela experiência do cativeiro e posteriormente conquistaram a liberdade. Um deles, de um senhor, solteiro, e que tinha uma filha com a qual vivia desde a mais tenra idade; o outro, de uma viúva que não tivera filhos.

O primeiro testamento analisado foi ditado pela testadora Rufina Maria da Conceição a Galdino Temístocles, num sábado, 20 de maio de 1865. Na época, ela estava com mais de 70 anos de idade, com uma lucidez invejável para quem já tinha vivido tantas agruras ao longo da vida. Moradora na Rua da Senzala Velha, número 26, na freguesia do Recife, local onde foi realizado o ato, sob os olhares atentos e os ouvidos aguçados das testemunhas que conheceremos ao longo desta narrativa. Rufina veio a falecer quatro anos após, numa sexta-feira, 23 de julho de 1869. Portanto, quando fez o testamento, não estava prestes a morrer.

O segundo testamento investigado foi feito no leito, na freguesia de São José (atual bairro de São José), na Rua dos Pescadores, número 9, num sábado, 12 de julho de 1890. O testador, Bento Moncorvo da Costa, faleceu meses depois, mais exatamente na quintafeira, 27 de novembro daquele ano, pouco dias após o início do regime republicano.

Ao manusearmos a documentação cível da Comarca do Recife, disponível no Memorial da Justiça do Estado de Pernambuco, chamou-nos a atenção esses dois testamentos por algumas razões: queríamos saber o que revelariam os testamentos de duas pessoas, uma mulher e um homem, ambos retirados do continente africano na condição de escravizados, e posteriormente libertos; o que teriam a legar para os descendentes e/ou entes queridos no final da vida. Teriam conseguido adquirir bens materiais, malgrado terem vivido em cativeiro? Quais as condições de moradia? Círculos de amizade? Profissões? Professavam alguma religião? Acreditávamos que de alguma forma os testamentos poderiam nos revelar aspectos da vida dessas duas criaturas anônimas na historiografia, como tantos outros que foram arrancados de sua terra natal, transformados em escravizados e esquecidos para a posteridade.

Revista da ABPN • v. 12, n. Ed. Especial - Caderno Temático: "Africanos, escravizados, libertos biografias, imagens e experiências atlânticas” • agosto de 2020, p. $784-806$ 
Nosso objetivo principal é, portanto, dar voz e vez a esses dois africanos, simbolizando tantos outros que permanecem em meio à documentação dos arquivos por este Brasil afora, à espera de quem lhes possa fazer justiça, recuperando, na medida do possível, suas trajetórias de vida, tentando "ajustar as contas com o passado".2

Queremos ressaltar que os testamentos são de africanos, como já dito, Bento da Costa, que criara sua filha, Benedita Maria da Conceição, ao que nos parece, sem a presença da mãe; e Rufina Maria da Conceição, que não gerara filhos, "nem quando solteira, nem quando casada", como ela mesmo afirmara, razão pela qual parte do legado foi dirigido para a afilhada, que morava em Maceió. Para os africanos, mais precisamente para o povo ioruba, ${ }^{3}$ região de Rufina, possuir descendência tinha um grande significado, como aponta um antigo provérbio: "sem filhos, estás nu".

Segundo Del Priore:

Muitas mulheres e muitos filhos, no continente de origem, eram considerados sinal de riqueza, fecundidade e felicidade. Todos juntos trabalhavam a terra do patriarca da família. A virilidade era atributo fundamental de honra de um homem. Já a fecundidade das mulheres era louvada em todas as formas de arte: escultura, dança, pintura. A esterilidade feminina era vivida como uma maldição. "Sem filhos, estás nu", dizia um antigo provérbio ioruba. (DEL PRIORE, 2005, p. 59).

No caso de Rufina, de não ter gerado descendência biológica, havia "arranjos", como, por exemplo, "adotar afilhados", assumir a "maternidade" de crianças mais próximas. As tão conhecidas "tias", que, nos grandes centros, como Rio de Janeiro, no pós-abolição, tiveram papel preponderante no acolhimento de crianças e adultos, constituindo famílias extensas, ao som do batuque do samba, a exemplo de Hilária Batista de Almeida, a "tia Ciata”, na Pequena África preconizada por Heitor dos Prazeres ${ }^{4}$

\footnotetext{
${ }^{2}$ Sobre a presença da cultura material e imaterial de africanos e seus descendentes na cidade do Recife, ver: SILVA, José Bento Rosa da. O Paraíso do Catimbó: Recife nas primeiras décadas do século XX. Revista da $A B P N$, v. 11, n. 29, jun.-ago. 2019, p. 174-197.

${ }^{3}$ Povo da África ocidental. Os iorubas, que constituem um dos três maiores grupos étnicos da República da Nigéria, vivem no oeste do país. A respeito, ver: LOPES, Nei. Enciclopédia Brasileira da Diáspora Africana. São Paulo: Selo Negro, 2004, p. 344.

${ }^{4}$ Pequena África é nome dado por Heitor dos Prazeres a uma região do Rio de Janeiro compreendida na zona portuária do Rio de Janeiro (Saúde, Gamboa e Santo Cristo, desde a Praça Mauá até a Cidade Nova), onde se encontra a Comunidade de Remanescentes de Quilombos da Pedra do Sal (ver: https://pt.wikipedia.org/wiki/Pequena \%C3\%81frica. Acesso em: 17/04/2020).
}

Revista da ABPN • v. 12, n. Ed. Especial - Caderno Temático: "Africanos, escravizados, libertos biografias, imagens e experiências atlânticas” • agosto de 2020, p. 784-806 
O principal documento que serviu de baliza para que pudéssemos revelar o que Bento e Rufina legaram à posteridade foi o testamento. A partir dele, fomos rastreando o nome de pessoas e lugares por onde eles passaram, fazendo uma espécie de arqueologia, e construindo a possibilidade de acontecimentos passados.

\section{RUFINA: UMA MORADORA DA RUA DA SENZALA VELHA}

Quando da preparação do testamento, Rufina morava numa casa térrea, sob o número 26 da referida rua. Rua onde também morou um outro africano, cuja trajetória de vida foi recentemente recuperada pela historiografia, a partir da metodologia da MicroHistória (REIS; GOMES; CARVALHO, 2010). Estamos nos referindo a Rufino José Maria, que ficou mais conhecido como Alufá Rufino, por professar a religião islâmica. ${ }^{5}$ Por essa época, era uma rua movimentada: na casa número 36, primeiro andar, alugavamse pretas para vender na rua, segundo notícia de jornal, "pagava-se bem" (DIARIO DE PERNAMBUCO, 22/04/1863, p. 4) com casas de comércio, entre elas, Silva \& Alves, "com variado sortimento das vendas de maquinas-norte americanas, para descaroçar algodão" (JORNAL DO RECIFE, 06/05/1866, p. 3). Havia, inclusive, vagas para um caixeiro numa casa de comércio, mas uma das exigências era que fosse "um destes meninos chegados do Porto" (DIARIO DE PERNAMBUCO, 01/01/1865, p. 4). Também foi nessa época que uma vizinha de Rufina precisava "de uma ama que [soubesse] cozinhar e que [fizesse] o serviço interno e externo de uma casa de pouca família: tratar na rua da Senzala Velha, n. 22, segundo andar" (DIARIO DE PERNAMBUCO, 16/02/1865, p. 4). No ano anterior, não sabemos se esses mesmos moradores, nos mesmos endereços, precisavam de uma "ama que [tivesse] bom leite e sem filho" (DIARIO DE PERNAMBUCO, 14/01/1864, p. 4). Um sobrado de um andar e sótão, vizinho da casa de Rufina, mais exatamente o número 29, estava em leilão. Um anúncio publicado no Jornal do Recife em 26/08/1865 na página 2 dá conta de que o imóvel rendia um aluguel de 460\$000 (quatrocentos e sessenta mil réis). Na figura reproduzida a seguir, vê-se que

\footnotetext{
${ }^{5}$ Alufá: "Sacerdote do culto malê [...] Do árabe alfa, 'sábio', 'sagaz', através do iorubá alufá. Na hierarquia sacerdotal do culto malê, cada grupo de alufás era chefiado por um lemane” (LOPES, 2004, p. 51).
}

Revista da ABPN • v. 12, n. Ed. Especial - Caderno Temático: "Africanos, escravizados, libertos biografias, imagens e experiências atlânticas” • agosto de 2020, p. $784-806$ 


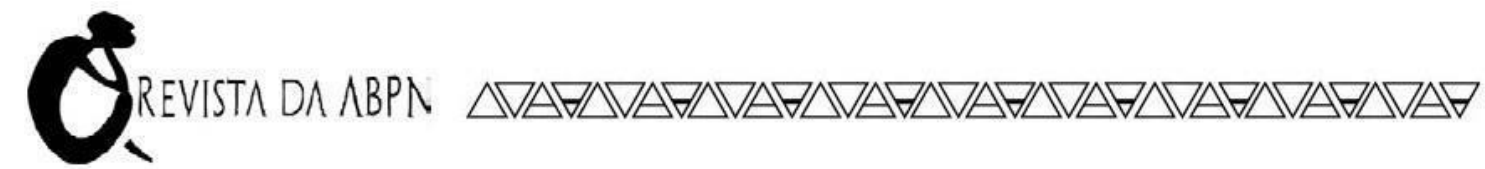

a concentração de casas de comércio estava relacionada à proximidade com o Cais da Alfândega.

Figura 1: Mapa de 1854 de parte da Freguesia do Recife

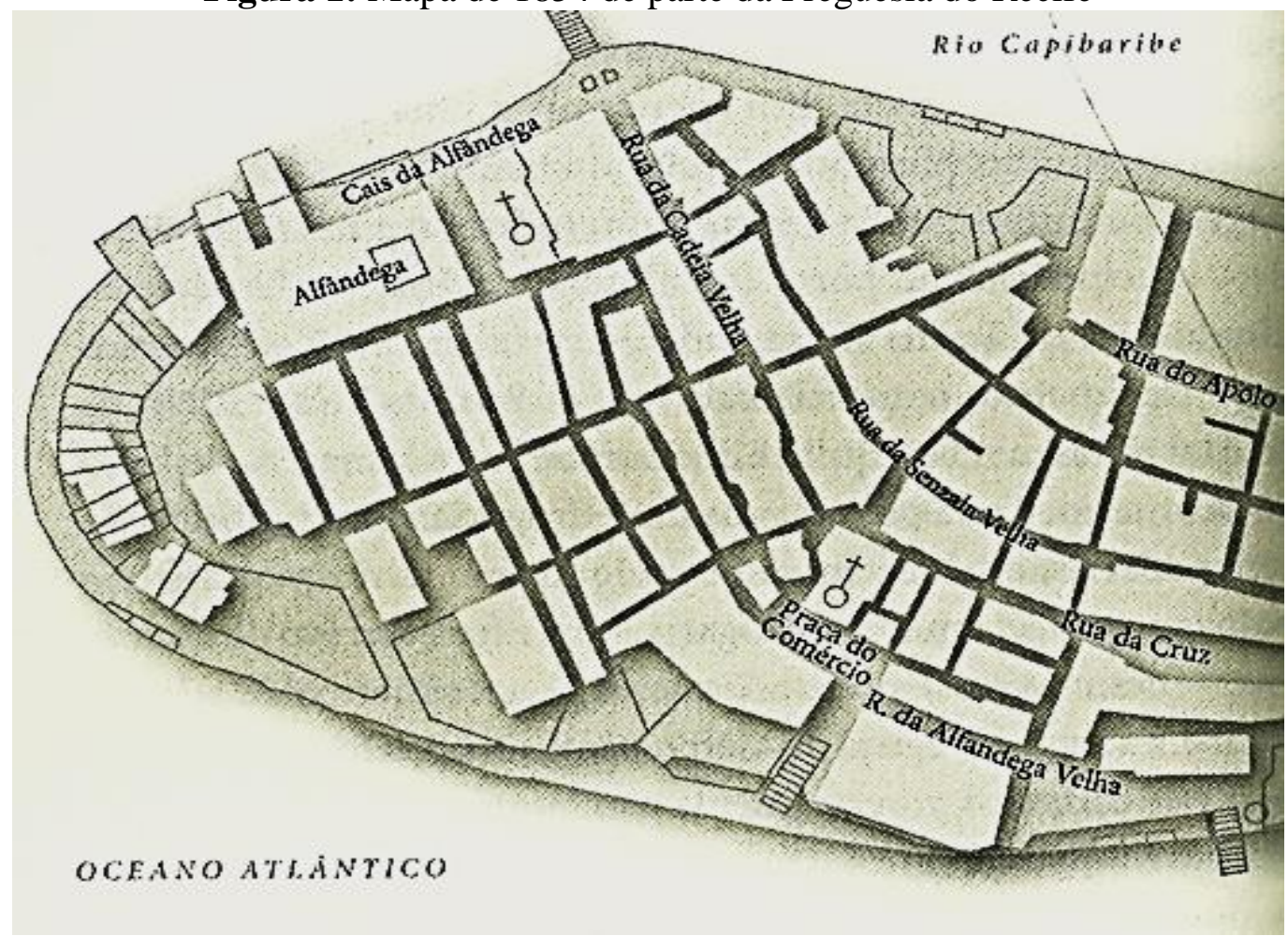

Fonte: GUILLEN (2017).

Não sabemos há quanto tempo àquela altura Rufina residia ali, na casa de sua propriedade, mas sabemos, por seu próprio depoimento, que havia tido uma única senhora, a africana forra, Luíza Maria de Mendonça, que, além de Rufina, foi senhora de outras mulheres escravizadas. Identificamos algumas delas, que tiveram os nomes veiculados nos jornais locais. Façamos, pois, um intervalo na narrativa da personagem

Revista da ABPN • v. 12, n. Ed. Especial - Caderno Temático: "Africanos, escravizados, libertos biografias, imagens e experiências atlânticas” • agosto de 2020, 
Rufina Maria da Conceição para sabermos um pouco mais daquela, que de uma forma ou outra, fez parte de sua História, ainda que em condições adversas.

\section{LUÍZA MARIA DE MENDONÇA: EX-PROPRIETÁRIA DE RUFINA}

Luíza Maria de Mendonça era "uma preta forra, de nação Calabar, moradora na cidade do Recife em Fora-de-Portas" ${ }^{\circ}$, segundo depoimento de Faustina, uma escrava que foi encontrada no Engenho Pindobinha, em 1846. Faustina e outras haviam sido roubadas e vendidas para o dono do referido engenho. Não sabemos a quem Faustina pertencia, mas ela disse ter conhecido no Pindobinha uma escrava de nome Maria, Angola, de 15 a 16 anos, de propriedade de Luíza Maria de Mendonça (DIÁRIO NOVO, 07/02/1846, p. 3; 23/02/1846, p. 3). Jerônimo Albuquerque de Mello foi acusado por José Caetano Teixeira de ter comprado escravos roubados e foi a júri popular. Foi condenado a 9 anos de galés e a pagar $25 \%$ do valor dos escravos e as custas do processo (DIARIO DE PERNAMBUCO, 06/08/1846, p. 1).

Outras informações acerca da forra Luíza: havia solicitado permissão às autoridades para embarcar sua escrava Rosa, de nação Angola, para a cidade do Rio de Janeiro. Autorização concedida, Rosa embarcou no dia 28 de agosto de 1843 (DIARIO DE PERNAMBUCO, 23/08/1843, p. 4; 28/08/1843, p. 9). Talvez Luíza tivesse algum negócio na Corte, pois encontramos Rosa embarcando novamente para a capital em agosto do ano seguinte (DIÁRIO NOVO, 29/08/1844, p. 4). Também identificamos a presença majoritária de escravas no "plantel” de Luíza.

Sabemos que Luíza era solteira e que deixou um testamento, mas até o momento não o identificamos nos arquivos pesquisados. ${ }^{7}$ Ela faleceu aos 50 anos de idade, no dia 13 de novembro do ano de 1844. Nessa época, Rufina já havia conquistado sua liberdade, como veremos adiante (DIÁRIO NOVO, 03/12/1844, p. 3).

Não parece ter sido fácil para Luíza Maria de Mendonça, uma africana forra, solteira, lidar com propriedades, numa sociedade escravocrata, patriarcal e machista por

\footnotetext{
6 Antigo povoado da cidade do Recife, hoje denominado Comunidade do Pilar (https://pt.wikipedia.org/wiki/Fora-de-Portas).

${ }^{7}$ Nas notícias veiculadas sobre o Tribunal do Júri que condenou Teixeira, foi mencionada a existência de um testamenteiro de Luíza Maria de Mendonça (DIÁRIO NOVO, 25/02/1846, p. 3).
}

Revista da ABPN • v. 12, n. Ed. Especial - Caderno Temático: "Africanos, escravizados, libertos biografias, imagens e experiências atlânticas” • agosto de 2020, p. 784-806 
excelência. Dizemos isso pelas pistas que encontramos acerca do seu cotidiano. No ano de sua morte, em 1844, uma de suas escravas foi roubada. Ela tinha um suspeito - ao que nos parece, não era um desconhecido:

Furtaram no dia 11 de julho p.p, uma negra de nome Maria, idade de 13 anos, nação Cambundá, cara comprida, nariz afilado, olhos grandes, a dita preta é escrava de Luiza Maria de Mendonça, moradora em Fora de Portas, n. 35, desconfia-se estar vendida para o Rio Grande do Norte; quem der notícia certa terá $100 \$$ rs. Desconfia-se ter sido furtada por um pardo conivente com um português, os quais levaram carregada por um preto para o embarque. (DIARIO DE PERNAMBUCO, 15/08/1844, p. 3).

Não bastasse isso, havia os que queriam enganá-la, como foi o caso de Caetano Teixeira, aquele mesmo que posteriormente a roubaria, embora ela já não estivesse mais viva para ver. Na ocasião da tentativa de estelionato, ela foi a público, em mais de uma edição, esclarecer: "que não se responsabiliza por qualquer quantia que José Caetano Teixeira tenha feito por seu nome" (DIÁRIO NOVO, 05/08/1844, p. 3).

\section{RUFINA MARIA DA CONCEIÇÃO: DO CATIVEIRO À LIBERDADE}

Rufina nasceu livre, na "nação Calabar". Depois tornou-se uma cativa ${ }^{8}$, mas por pouco tempo, pois levou sorte, se comparada com os demais que com ela foram embarcados. Não sabemos se sorte ou astúcia, pois não estamos a par do processo como ela se libertou. Uma coisa é certa: ela pagou o seu preço. Talvez sorte somada a astúcia.

Segundo Nei Lopez, Calabar é uma cidade localizada no sudoeste da atual República Federal da Nigéria, capital do estado de Cross River, principal núcleo do povo Efik. O nome Calabar foi dado no Brasil a todos os africanos procedentes da região dos Efiks, como Ibos e Edos, entre outros (LOPES, 2004, p. 153). Portanto, Rufina era da mesma nação que sua ex-proprietária, Luíza Maria de Mendonça. Não sabemos exatamente com qual a idade estava à época em que fez o testamento, segundo ela, teria

\footnotetext{
8 "Na África, [...] os cativos eram os africanos trazidos pelos pombeiros ou por outros intermediários até o litoral africano, onde eram negociados com os traficantes encarregados de sua venda no mercado dos países ou regiões compradoras de escravos. No litoral, os negros eram comprados e depois ferrados. Somente após terem sido adquiridos, marcados e batizados, eram considerados escravos" (MOURA, 2004, p. 95).
}

Revista da ABPN • v. 12, n. Ed. Especial - Caderno Temático: "Africanos, escravizados, libertos biografias, imagens e experiências atlânticas” • agosto de 2020, p. 784-806 
mais de 70 anos, portanto, deve ter nascido no final do século XVIII. Melhor do que falar dela, é ouvir o que ela declarou diante das testemunhas:

Declaro que me chamo Rufina Maria da Conceição, nação calabar, vinda da África para a cidade da Bahia, e dali para esta cidade no ano de mil oitocentos e vinte e quatro, e apenas vendida a preta Luisa Maria de Mendonça, já falecida, do seu poder me libertei pela quantia de duzentos e cinquenta mil réis (250\$000) seguramente no ano de 1827, devendo ter hoje mais de setenta anos. (Testamento de Rufina Maria da Conceição, 1869, caixa 1165, folha 2).

A rota da viagem de Rufina foi a mesma descrita por Bento Moncorvo: da Costa da África para a Bahia, e depois para a cidade do Recife. Pierre Verger levantou uma farta documentação acerca da relação entre o Golfo do Benin e a Bahia de Todos os Santos. Mas havia rotas diretas da África para o Recife, tanto de navios negreiros quanto de navios de passageiros, como anunciavam os jornais da época:

Para Luanda com escala por Benguela, o bergantim brasileiro Temerário, chegado proximamente de Lisboa, é a primeira vez que se destina a África, sairá com muita brevidade: quem quiser carregar ou ir de passagem, dirigir-se a seu capitão, Domingos Francisco da Silva, ou a Manoel Francisco Pontes, na rua da Senzala Velha. (DIARIO DE PERNAMBUCO, 17/04/1841, p. 4).

Há um navio de lote de 200 toneladas, que se propõe ir para a Costa da África, Benguela e Angola; tem metade do carregamento pronta. A quem convier carregar a outra metade, ainda por conta de diversos carregadores, pode dirigirse defronte ao Trapiche Novo, número 10, terceiro andar, que achará com quem tratar. (DIARIO DE PERNAMBUCO, 17/04/1846, p. 3).

A região da qual Rufina foi forçosamente retirada era, de fins do século XVIII até a metade do XIX, uma verdadeira sangria de africanos transformados em "peças" para serem comercializados, como mostram os controversos dados do tráfico atlântico ${ }^{10}$. Um dos envolvidos no tráfico nessa região era o baiano Francisco Félix de Souza, o Chachá, conforme investigação aguçada de Alberto da Costa e Silva (2004). Talvez Rufina tenha sido uma de suas vítimas. Para se ter uma ideia do panorama na região, vejamos o que escreveram dois dos maiores africanistas do século XX, Oliver e Fage (1980, p.175):

\footnotetext{
${ }^{9}$ Era esse o conceito utilizado para os africanos escravizados no contexto do tráfico atlântico.

${ }^{10}$ Visitando o The Trans-Atlantic Slave Trade Database (https://www.slavevoyages.org/), é possível ter uma dimensão do horror e da violência com que foi conduzido o tráfico negreiro no Atlântico.
}

Revista da ABPN • v. 12, n. Ed. Especial - Caderno Temático: "Africanos, escravizados, libertos biografias, imagens e experiências atlânticas” • agosto de 2020, p. $784-806$ 
O aumento do poder britânico na Costa do Ouro fê-la aproximar-se mais dos acontecimentos cada vez mais agitados dos territórios mais a leste. Havia aqui em ação duas tendências aparentemente contrárias. Na Costa dos Escravos o reino do Daomé e os exportadores europeus para o Brasil e Cuba prosperavam, como nunca antes, mercê do tráfico de escravos. A maioria dos escravos provinha de um território ioruba onde o império de Oyo mergulhava na guerra civil e na anarquia.

O desembarque de Rufina no Brasil foi no tenso ano de 1824, quando da outorga da primeira Constituição da Confederação do Equador ao nordeste do Império, justamente onde ela desembarcara. Nunca tivera nenhuma outra proprietária. Três anos após, em 1827, conquistou a liberdade ao pagar duzentos e cinquenta mil réis, que deve ter acumulado de formas diversas, talvez como escrava ao ganho. Talvez fora nesse momento que ela teria ido morar na Rua da Senzala Velha, deixando sua ex-senhora lá em Fora-dePortas. Chama-nos a atenção a sua segurança quanto ao ano em que conquistou sua liberdade: "seguramente no ano de 1827" (Testamento de Rufina Maria da Conceição, 1869, caixa 1165 , folha 2 ).

Rufina declarou-se viúva do "preto José Moreira", como ela denominou seu esposo, sobre o qual pouco sabemos. Não tiveram filhos. Ela foi a única herdeira dele. Em virtude do seu testamento, infere-se que ele já deveria ser liberto quando morreu. Frisa-se no testamento de Rufina que prestou conta de tudo isso à Fazenda Imperial, estando, então, com a consciência tranquila "perante Deus e os homens". Talvez cumprindo o ensinamento do evangelho: "Dai, pois, a César o que é de César, e a Deus o que é de Deus" (MATEUS, 22:21), uma vez que era uma católica convicta e integrante da Irmandade de São Benedito do Convento de Santo Antônio. Esperava, assim, ter uma morte decente, ou seja, "uma boa morte", que consistia, entre outras coisas, na celebração e encomendação do corpo e da alma, e em ter uma sepultura digna, daí a importância de estar filiada a uma Irmandade, pois de certa forma era como uma família:

Declaro que sigo e professo a religião católica apostólica romana, que em sua fé tenho vivido e espero morrer. [...] Declaro que fui casada com o preto José Moreira, já falecido, do qual não tive filhos, também não os tive nem antes, nem depois de casada, sendo herdeira da meação do meu finado marido em virtude do seu testamento, dele prestei contas, achando-me com a Fazenda, e com o juiz, quite de ação, pelo que meus bens estão livres e desembaraçados, nada devendo a pessoa alguma. Declaro que sou irmã remida da Irmandade de São Benedito do

Revista da ABPN • v. 12, n. Ed. Especial - Caderno Temático: "Africanos, escravizados, libertos biografias, imagens e experiências atlânticas” • agosto de 2020, p. $784-806$ 
Convento de Santo [Antônio], a cuja mesa se participará para tratar do meu enterro, ajudando meu testamenteiro com o que haver [sic] para que seja enterrada com toda decência. (Testamento de Rufina Maria da Conceição, 1869, caixa 1165 , folhas 2-2v).

Na sequência, a testadora declara não ter dinheiro de espécie alguma, e que seus bens consistiam na morada térrea onde ela residira, situada na Rua da Senzala Velha, número 26, e algumas pedras de ouro, poucas, para a manutenção dos seus sustentos. E parece nos dizer que o que tinha era fruto do seu trabalho, que não havia herdado nada de ninguém e que não tinha pais, tampouco filhos para quem deixar seus parcos bens. E mais: que dispunha dos bens como lhe aprazia.

A Irmandade de São Benedito do Convento de Santo Antônio foi a melhor aquinhoada com os poucos bens de Rufina, inclusive, em cumprimento de um desejo de José Moreira, seu falecido esposo, que só não havia doado à Irmandade quando de sua morte, porque não tinha outros bens, e era onde sua esposa morava, não tendo ela para onde ir, caso a doação fosse concretizada por ele, ao menos foi esta a leitura que fizemos desta parte do testamento de Rufina:

[...] Declaro que era vontade do meu finado marido Jose Moreira doar esta casa com que moro, à Irmandade de São Benedito do Convento de Santo [Antônio], no que eu concordava, não havendo este feito em sua vida, atendendo a não haver outro bem, e não tendo eu mesa do devontade, e por respeito faço dela doação a referida Irmandade, para que a possua como estou possuindo, e peço que a respectiva mesa faça celebrar por minha alma dez missas de corpo presente e dez de sétimo dia. Para que se possa realizar esta doação, meu testamenteiro logo que eu falecer avisará logo a Irmandade desta minha disposição para que ela promova a necessária licença para possui-la. (Testamento de Rufina Maria da Conceição, 1869 , caixa 1165 , folha 3 ).

Rufina não era uma pessoa letrada, como ela mesma declarou no testamento, e até mesmo porque não era comum ex-escravizados letrados, por conta da legislação escravista $^{11}$, mas isso não lhe tirou a capacidade de discernimento acerca de como encaminhar os resíduos de seus bens materiais, inclusive buscando alternativas caso houvesse obstáculos. Na linguagem de hoje, diríamos que ela construiu um "plano b",

\footnotetext{
${ }^{11}$ Atente-se para o parágrafo terceiro do artigo 69 do Decreto n ${ }^{\circ}$ 1.331-A, de 17 de fevereiro de 1854: "Art. 69. Não serão admittidos á matricula, nem poderão frequentar as escolas: $\S 1^{\circ}$ Os meninos que padecerem molestias contagiosas. $\S 2^{\circ}$ Os que não tiverem sido vaccinados. $\S 3^{\circ}$ Os escravos". (BRASIL, 1854, v. 1, p. 45).
}

Revista da ABPN • v. 12, n. Ed. Especial - Caderno Temático: "Africanos, escravizados, libertos biografias, imagens e experiências atlânticas” • agosto de 2020, p. 784-806 
caso a Irmandade encontrasse empecilhos legais para possuir os bens que ela, legatária, deixava para os irmãos e irmãs da Irmandade do venerável São Benedito. E mais: a Irmandade não gastaria nenhum centavo dos seus cofres para as despesas com o seu féretro, pois, com a aplicação sugerida, as despesas seriam feitas com o resultado dos frutos gerados pelo investimento advindo do imóvel doado. Isso nos revela muito do conhecimento de Rufina do "mundo dos negócios", ou das formas de sobrevivência de uma africana forra na década de 60 do Recife oitocentista. Vejamos como ela instruiu o primeiro testamenteiro ${ }^{12}$ no ato da confecção do testamento:

Para que se possa realizar esta doação, meu testamenteiro logo que eu falecer avisará logo a Irmandade desta minha disposição para que ela promova a necessária licença para possui-la, e caso não o consiga de acordo com ela e com ordem do Provedor dos Resíduos, converterão o valor dela em apólices da dívida pública, meu testamenteiro a alugará aplicando o aluguel em fazer celebrar duas missas por minha alma, e duas por alma de meu marido, e logo que a referida Irmandade tomar posse da casa ou do seu valor convertido em apólices, cessará a obrigação do meu testamenteiro, e passará para a Irmandade o seguinte: mandará celebrar por minha alma duzentas missas, e duzentas por alma do meu marido José Moreira, as quais serão celebradas ou com o aluguel da casa, ou com o juro das apólices, e quer num, quer noutro caso, só se celebrarão as missas, que puderem celebrar com a metade do rendimento porque a outra metade pertence a Irmandade para as despesas do culto, promovido anualmente em juízo que cumpriu esta disposição e constante do aluguel em que deste não se efetua a entrega da casa o meu testamenteiro aplicará com as despesas necessárias, que tiver se fazer. Do restante dos meus bens, intitulo por herdeira a minha afilhada, Ignês, casada com Ismael, moradores em Maceió. (Testamento de Rufina Maria da Conceição, 1869, caixa 1165, folha 3).

Cinco dias após ter sido feito o testamento, o mesmo foi aprovado pelo tabelião público de notas, João Batista de Sá, que esteve presente no mesmo endereço onde fora confeccionado o documento. Testemunharam a aprovação as seguintes pessoas: "João Pereira da Silva, casado, artista; José Antônio Pereira da Silva, casado, artista; Eufrásio José Ribeiro, casado, artista; Guilherme de Souza Barros, solteiro, artista; Antônio de

\footnotetext{
${ }^{12}$ Foram escolhidos três testamenteiros: O primeiro foi Victor Antônio do Sacramento, que foi mesário na eleição da Irmandade dos homens pretos de Nossa Senhora D'Assumpção da Imperial Capela das Fronteiras da Estância, do mestre de campo Henrique Dias. Ele era escrivão nessa irmandade. Foi professor de instrução primária. Foi escrivão da Irmandade de Nossa Senhora do Rosário da freguesia de Santo Antônio. (DIARIO DE PERNAMBUCO, 01/04/1854, p. 3; 29/08/1867, p. 4). O segundo testamenteiro foi Manoel Tertuliano dos Reis, paroquiano da freguesia do Recife, que assinou um manifesto liberal (DIARIO DE PERNAMBUCO, 21/01/1867). O terceiro foi o tesoureiro da Irmandade de São Benedito, cujo nome não foi mencionado.
}

Revista da ABPN • v. 12, n. Ed. Especial - Caderno Temático: "Africanos, escravizados, libertos biografias, imagens e experiências atlânticas” • agosto de 2020, p. $784-806$ 
Deus Mandiogue [ou Mandioque], solteiro, comerciante: todos moradores neste bairro" (Testamento de Rufina Maria da Conceição, 1869, caixa 1165, folha 5). Acreditamos serem pessoas do círculo dela: artesãos e comerciantes. Suspeitamos que Antônio de Deus fosse africano, pelo sobrenome incomum. Destes não identificamos nenhum que estivesse como testemunha, cinco dias antes, no momento em que se ditou o testamento. ${ }^{13}$

A notícia da morte de Rufina Maria da Conceição foi veiculada no Diario de Pernambuco, na edição da terça-feira, 27 de julho de 1869, na segunda página, na coluna Cemitério Público: "Rufina Maria da Conceição, África, 75 anos, casada, Recife, herysipela". Ela falecera, segundo o testamenteiro Victor Antônio do Sacramento Pessoa, às seis horas da tarde do dia 22 de julho de 1869.

As pistas deixadas pelo testamento de Rufina Maria da Conceição, a africana que involuntariamente chegou à cidade do Recife na década de 20 do século XIX e que faleceu na década de 60 do mesmo século, possibilitou-nos, entre outras coisas, evidenciar o perfil de mulheres que lutaram pela liberdade. Algumas conseguiram, como essa Calabar. Outras não conseguiram, morreram sob o jugo da escravidão, mas certamente não se deixaram escravizar; foram, na medida do possível, agentes de sua História.

No testamento de Rufina não encontramos uma herança acumulada à espera dos herdeiros que se digladiassem entre si pelos bens, como era comum acontecer com as famílias abastadas. Sequer encontramos herdeiros consanguíneos, mas encontramos herdeiros construídos ao longo de sua vida, que de certa forma foram dignos de herdar o pouco que Rufina e José Moreira construíram ao longo de suas vidas, malgrado as condições adversas.

Para além das seis páginas, o testamento proporcionou-nos a possibilidade de, a partir dele, investigar o tempo vivido por Rufina na cidade do Recife. Apresentou-nos pessoas que, de uma forma ou de outra, fizeram parte da vida da nossa personagem, como, por exemplo, a sua conterrânea, que nos parece ter sido trazida para o Império do Brasil na mesma condição de Rufina, mas que, posteriormente, já forra, tornou-se uma proprietária de escravizados, tendo, inclusive, Rufina como propriedade, ainda que por pouco tempo.

\footnotetext{
${ }^{13}$ Referências de algumas das testemunhas que estiveram no ato da aprovação do testamento: José Pereira da Silva, marceneiro estabelecido na Rua da Guia, n. 3; José Antônio Pereira da Silva, inspetor de quarteirão (JORNAL O LIBERAL, 01/05/1869, p. 1; O CONSTITUCIONAL, 21/08/1861, p. 2).
}

Revista da ABPN • v. 12, n. Ed. Especial - Caderno Temático: "Africanos, escravizados, libertos biografias, imagens e experiências atlânticas” • agosto de 2020 , p. $784-806$ 
Informações contidas no testamento nos levaram aos periódicos, que nos descortinaram aspectos que não estavam diretamente inseridos no documento analisado, tais como a Rua da Senzala Velha da época de Rufina Maria da Conceição e suas adjacências (Cais da Alfândega, Rua da Cadeia, Rua dos Pescadores etc.). Fazendo uma analogia, o testamento foi apenas uma ponta do iceberg. Fizemos uma pequena imersão para além da ponta e descobrimos que era bem maior do que aparentava ser. As seis laudas manuscritas do testamento duplicaram-se e metamorfosearam-se na primeira parte deste texto, que segue com a História de um outro africano que nos legou um testamento nas primeiras décadas da República Federativa dos Estados Unidos do Brasil, quando a abolição da escravidão era um fato consumado, malgrado as permanências vividas pelos ex-escravizados.

\section{BENEDICTO BENTO DA COSTA}

É comum encontrarmos no Brasil descendentes de africanos com os nomes Benedito e Benedita, sobretudo nas regiões onde predominou o trabalho dos africanos escravizados e seus descendentes. Consultando a documentação do período escravista, com frequência encontramos os Beneditos e Beneditas nos plantéis dos senhores e senhoras de escravos. Em nossa opinião, esse fato está relacionado ao processo de catequização da Igreja Católica sobre os escravizados, no qual eram "eleitos" alguns santos como padroeiros dos escravos, entre eles, São Benedito, nascido na Itália no século XVI e de ascendência africana (QUINTÃO, 2002; REGINALDO, 2009; REIS, 1996). Não é demais lembrar que Bento é uma síncope de Benedito, palavra que, por ironia do destino, etimologicamente significa: abençoado, bendito.

Nosso personagem chamava-se Bento Moncorvo da Costa, nascido na Costa da África e forçosamente trazido como escravizado, mais uma vítima do cativeiro. Não sabemos qual era seu nome em África, tampouco se seu segundo nome, Moncorvo, tem origem naquele continente ou se foi apropriação do nome ou sobrenome de um antigo senhor. Diferentemente de Rufina, não sabia quando desembarcara no Império do Brasil, mas disse da trajetória que percorrera para chegar na capital da província de Pernambuco: "sou natural da Costa da África, e deste lugar parti para o Estado da Bahia, e dali para o

Revista da ABPN • v. 12, n. Ed. Especial - Caderno Temático: "Africanos, escravizados, libertos biografias, imagens e experiências atlânticas" • agosto de 2020 , 
de Pernambuco, onde atualmente resido por tempo superior a doze anos" (Testamento de Bento da Costa, 1890, caixa 253, folha 2); portanto, a mesma rota trilhada por Rufina.

Há também na documentação investigada muitos sobrenomes comuns entre os escravizados, Costa é um deles. Isso se deve ao fato de terem sido tirados de uma mesma região. Um sobrenome ou nome de família inventado no processo da diáspora africana. Manuseando os jornais da época em que Bento Moncorvo da Costa ditou seu testamento, encontramos na coluna Necrologia o registro de falecimento de muitos africanos da Costa, todos eles já com idade avançada, moradores na sua grande maioria nas freguesias (bairros) de Boa Vista, Recife, São José e Santo Antônio. Os dados apresentados no obituário eram: nome, estado civil, localidade de nascimento, idade, freguesia e doença que levou a óbito. Vejamos alguns casos no período compreendido entre 1890 e 1891 , colhidos no jornal A Província: Zacaria da Costa, África, 65 anos, São José, tétano espontâneo (fevereiro de 1890); José Baptista da Costa, África, 81 anos, solteiro, congestão cerebral (abril de 1890); Sophia da Costa, África, 80 anos, solteira, Boa Vista, cachexia senil (julho de 1890); Raphael da Costa, África, 70 anos, solteiro, São José, cachexia senil(agosto de 1890); Fernandes da Costa, África, 90 anos, solteiro, Santa Águeda, varíolas (outubro de 1890); José da Costa, África, 60 anos, solteiro, Boa Vista, pneumonia (fevereiro de 1891); Lourenço José da Costa, África, 98 anos, solteiro, São José, cachexia senil (junho de 1891); Joaquina da Costa, África, 65 anos, solteira, São José, tubérculos pulmonares (junho de 1891); João da Costa, África, 75 anos, solteiro, Boa Vista, anemia (julho de 1891); Maria do Bonfim da Costa, África, 80 anos, solteira, São José, lesão cardíaca (julho de 1891); Cypriano da Costa, África, 75 anos, solteiro, São José, hérnia estrangulada (julho de 1891) Libório da Costa M., África, 80 anos, casado, Boa Vista, lesão cardíaca (agosto de 1891); José da Costa, África, 85 anos, solteiro, Boa Vista, enterite (setembro de 1891); Narcisa da Costa, África, 62 anos, solteira, São José, inflamação do útero (outubro de 1891); e Luiz Francisco da Costa, África, 90 anos, solteiro, Boa Vista, tubérculos pulmonares (novembro de 1891).

É preciso dizer que nem todos os óbitos de africanos com o sobrenome da Costa foram noticiados. Uma prova disso é que não encontramos o de Bento Moncorvo da Costa, ocorrido em 27 de novembro de 1890, meses depois de ter ditado o seu testamento. Moncorvo vivia com sua filha, Benedita Maria da Conceição, que foi a testamenteira.

Revista da ABPN • v. 12, n. Ed. Especial - Caderno Temático: "Africanos, escravizados, libertos biografias, imagens e experiências atlânticas” • agosto de 2020, p. $784-806$ 
Não sabemos que idade tinha ao falecer, mas identificamos que era solteiro, morava na Rua dos Pescadores, na freguesia de São José, nas proximidades do Cais de Santa Rita. Para adquirir sua casa própria, tomou emprestado a quantia de $500 \$ 000$ (quinhentos mil réis) de Lucrécia Maria da Conceição, com quem dividia seu único imóvel, conforme sua declaração.

A presença de africanos na freguesia de São José, onde morava Bento da Costa, era uma das mais significativas nesse período - a leitura no quadro necrológico acima com o registro dos óbitos dos Da Costa evidencia o que estamos afirmando. Um panorama da rua no ano de 1890: na casa número 3 havia a quitanda de Carlos Alberto de Abreu, que, diga-se de passagem, estava com dívidas com a municipalidade (vários impostos), relativa aos anos de 1886 e 1887 no valor de $4 \$ 000$ (quatro mil réis) (A PROVÍNCIA, 29/04/1890, p. 2-3); o comércio Lopes \& Oliveira, sob o número 43; sob o número 6, estava o comércio de Antônio Joaquim Moraes e Silva, também com o nome sujo na praça, pois devia à municipalidade $15 \$ 085$ (quinze mil e oitenta e cinco réis) (A PROVÍNCIA, 20/05/1890, p. 2); havia sob o número 18 o Club Carnavalesco dos Palhaços (JORNAL DO RECIFE, 11/05/1890, p. 2); e ainda havia uma boa oferta para quem ali quisesse fixar residência: "Vende-se uma taverna na rua dos pescadores, n. 43, com poucos fundos e bons cômodos para família; tratar na mesma" (DIARIO DE PERNAMBUCO, 17/04/1890, p. 5).

Havia também nessa freguesia uma comissão para o tratamento da varíola, cujo coordenador até o mês de agosto de 1890 era o Dr. Barros Carneiro (DIARIO DE PERNAMBUCO, 23/08/1890, p. 3). A varíola que, segundo a edição do Diario de Pernambuco de 25 de abril de 1890, "grassava com intensidade na capital".

Identificamos um certo mal-estar na freguesia de São José, onde morava Bento da Costa, em agosto de 1890. Um abaixo-assinado foi endereçado ao Dr. chefe de polícia, como noticiou o Jornal do Recife em sua edição de 31 de agosto daquele ano, sem revelar o conteúdo da missiva.

Do lado de dentro de sua casa, no referido bairro, Bento da Costa encontrava-se adoentado quando fez a declaração de seus bens em forma de testamento. Estava tão doente que necessitou um empréstimo para cuidar da sua saúde, hipotecando seu único imóvel:

Revista da ABPN • v. 12, n. Ed. Especial - Caderno Temático: "Africanos, escravizados, libertos biografias, imagens e experiências atlânticas” • agosto de 2020, p. $784-806$ 
Declaro mais, que precisando de dinheiro para meus negócios e para tratar a minha saúde, contrai em mãos da senhora Emília Maria da Conceição o débito de quatrocentos e cinquenta mil réis [450\$000], hipotecando a casa referida. Falecendo peço por não ter outros recursos que seja vendida a casa acima e deduzida as duas dívidas referidas, o restante seja de minha filha Benedita Maria da Conceição. (Testamento de Bento da Costa, 1890, caixa 253, folhas 2v-3).

Pressentindo o seu passamento, Bento hipotecou o seu patrimônio, pois, caso viesse a falecer, tinha como saldar as dívidas contraídas no valor de $950 \$ 000$ (novecentos e cinquenta mil réis): quinhentos mil para Lucrécia e quatrocentos e cinquenta para Emília. Acreditava ele ainda sobrar algum legado para a filha.

Tanto a primeira quanto a segunda pessoa que emprestaram dinheiro a Bento, possuíam sobrenomes semelhantes: Maria da Conceição. Aliás, era também o sobrenome da filha de Bento. Não acreditamos ser por laços de parentesco, mas possivelmente pela devoção à Nossa Senhora da Conceição.

Para testamenteiros, além de sua filha, Benedita Maria da Conceição, Bento Moncorceo da Costa convidou um amigo, também da Costa: "Rogo ao meu, digo, a minha filha Benedita Maria da Conceição e ao meu amigo Sabino Cristino da Costa, que queira fazer a obra pia de serem meus testamenteiros, na ordem em que estão colocados" (Testamento de Bento da Costa, 1890, caixa 253, folha 3).

Feito o testamento, fazia-se necessária a sua aprovação legal. Esta deu-se aos 12 dias do mês de setembro do mesmo ano de 1890, na residência de Bento Moncorvo. O ato deu-se da seguinte forma:

Saibam os que este público instrumento de aprovação de testamento virem, que no ano do nascimento de Nosso Sr. Jesus Cristo de 1890, aos doze dias do mês de setembro, nesta cidade do Recife, casa de morada de Bento Moncorvo da Costa, a rua dos Pescadores, freguesia de São José, onde eu tabelião, vim a chamado, ali encontrei doente de cama o mesmo Bento Mancorvo da Costa, está no gozo de seu juízo, segundo o meu parecer, em vista da coerência com que respondeu todas as perguntas que lhe dirigi em presença das testemunhas do que dou fé; bem como o dou de ser o próprio, por me garantirem a identidade de sua pessoa, as mesmas testemunhas. E logo perante as cinco testemunhas, no fim nomeadas e assinadas, o referido Bento Moncorvo da Costa, me entregou esta folha de papel, declarando que contava o seu testamento escrito pelo doutor Feliciano André Gomes, sob seu ditame, e me requerem que em razão do meu ofício, o aprovar e cerrar como é de lei. E recebendo, eu tabelião das próprias mãos do testador, este dito testamento, que li, verifiquei que nada tem que dúvida

Revista da ABPN • v. 12, n. Ed. Especial - Caderno Temático: "Africanos, escravizados, libertos biografias, imagens e experiências atlânticas” • agosto de 2020, p. $784-806$ 
faça, e se acha escrita da primeira a segunda página deste papel, que numerei com número um e rubriquei com a rubrica o Maranhão de que uso. E perguntando eu ao testador se com efeito é este o seu testamento que há por bem firmar e validar? Respondeu-me que sem dúvida é este o seu testamento, que há por bem firmar e validar, nada tendo que alterar da sua disposição.

Pelo que havendo, eu tabelião por aprovado este testamento quanto posso e me permite a citação o presente instrumento. (Testamento de Bento da Costa, 1890, caixa 253 , folha 3 ).

Testemunharam: Desidério Pedro de Arcanjo, José Bernardo Moura, João Batista Damaceno, Manoel Francelino de Ó, e Philomeno Athanásio da Silva. Este último assinou a pedido do testador, que não sabia ler nem escrever. Dessas testemunhas a única informação que consta no documento é que todos eram moradores da cidade do Recife, mas não obtivemos informações acerca da profissão, nacionalidade, naturalidade, estado civil, enfim, em que medida faziam parte do círculo de amizade do testador. Chamou-nos a atenção Manoel Francelino de Ó, por já termos encontrado africanos com esse sobrenome em outros documentos cartoriais (Memorial da Justiça do Estado de Pernambuco. Comarca do Recife. Processo Cível [Ação de Liberdade], caixa 249, ano 1884; DIARIO DE PERNAMBUCO, 29/07/1869). Encontramos uma referência dele dois anos após. Estava na lista dos devedores de impostos à intendência municipal do Recife, referente ao orçamento de 1882 a 1889. Seu endereço era Beco do Tambiá, número 21 , e devia a quantia de $5 \$ 500$ (cinco mil e quinhentos réis). ${ }^{14} \mathrm{O}$ referido beco ficava localizado na freguesia da Boa Vista.

Com a morte de Bento Moncorvo da Costa, a 17 de dezembro de 1890, foi aberto publicamente o testamento dez dias após o falecimento, ou seja, em 27 do então corrente mês. Embora a primeira testamenteira tenha sido sua filha, Benedita Maria da Conceição, quem parece ter tomado a iniciativa legal para abertura do testamento foi um certo Cyriaco Ferreira dos Santos, que até então não tinha participado de nenhum ato relacionado com o testamento de Bento da Costa, o que nos fez perguntar sobre quem seria tal pessoa e que lugar teria no convívio com o testador. Se bem que o documento dá algumas referências acerca dele: "preto, de maior idade", e nada mais que isso. O termo de abertura do testamento dizia:

\footnotetext{
${ }^{14}$ A lista continha 17 devedores do Beco do Tambiá. A maior dívida era no valor de $20 \$ 626$ (vinte mil seiscentos e vinte e seis réis); a menor era de $4 \$ 125$ (quatro mil cento e vinte cinco réis), segundo o Diario de Pernambuco (17/09/1892, p. 4).
}

Revista da ABPN • v. 12, n. Ed. Especial - Caderno Temático: "Africanos, escravizados, libertos biografias, imagens e experiências atlânticas” • agosto de 2020, p. $784-806$ 
Aos 27 dias de novembro de 1890, nesta cidade do Recife em casa do doutor juiz de direito[...] onde eu escrivão de seu cargo chamado vim, ali presente Cyriaco Ferreira dos Santos, preto, de maior idade, por ele foi entregue ao juiz um testamento cerrado de Bento Moncorvo da Costa, preto, que faleceu nesta cidade no dia dezessete do corrente mês. O juiz recebeu o testamento, abriu e verificou ser de que se trata, escrito e assinado a rogo do testador, por não saber ler e escrever, pelo bacharel Feliciano André Gomes, após ser verificado pelo tabelião. (Testamento de Bento da Costa, 1890, caixa 253, folha 5).

Teria Benedita Maria da Conceição, filha e primeira testamenteira de Bento da Costa, solicitado a Cyriaco que tomasse a providência de levar até o juiz o testamento? Quem era, afinal, Cyriaco Ferreira do Santos? Ele era um homem ligado à Irmandade de São Benedito do Convento dos Religiosos Franciscanos da Cidade do Recife. Fez parte como um dos secretários na eleição da referida irmandade no ano compromissal de 1888/1889 (DIARIO DE PERNAMBUCO, 15/05/1889, p. 5). Parecia um homem desembaraçado, pois, em fevereiro de 1891, ele estava entre os tripulantes que desembarcaram do vapor inglês Cometa, vindo do sul (DIARIO DE PERNAMBUCO, 17/02/1891, p. 3).

É possível que Bento Moncorvo da Costa tenha tido proximidade com Cyriaco mediada pela Irmandade, apesar de Bento não ter se declarado, como o fez Rufina, mas de uma forma ou de outra, a grande maioria dos africanos escravizados teve contato com as práticas religiosas católicas, o que muitas vezes era uma forma de recriar laços de pertencimento na diáspora.

Bento e Rufina se conheceram? É possível que não, mas os testamentos deles mostraram aproximações, tais como: a elaboração de um testamento para os herdeiros; ainda que não tivessem muitos bens a declarar, o fizeram em favor de pessoas ou instituições, que, como no caso de Rufina, fizeram parte de suas vidas. Tiveram praticamente um mesmo trajeto da Costa da África para a cidade do Recife, passando pela Bahia de Todos os Santos e Todos os Orixás. Conquistaram as suas liberdades e tiveram uma boa morte, pois os testamenteiros cumpriram o que lhes prometeram. Nos dois testamentos, constatamos a presença de africanos, afro-brasileiros e pessoas do círculo de amizade. Tiveram quem chorasse por eles, quem deles lembrasse, ao menos por algum tempo, antes de caírem no esquecimento da História, por terem sido pessoas "comuns". Ambos viveram no período imperial. Rufina, por exemplo, certamente pôde testemunhar

Revista da ABPN • v. 12, n. Ed. Especial - Caderno Temático: "Africanos, escravizados, libertos biografias, imagens e experiências atlânticas” • agosto de 2020, p. $784-806$ 
a Revolução Praieira, e quem sabe não teve alguma participação nela? Rufina vivenciou toda a década de 60 do século XIX, o advento das leis abolicionistas, a própria abolição e o fim do regime imperial.

\section{Considerações finais}

Os testamentos, segundo Júnia Ferreira Furtado, "são produzidos no contexto da morte de uma pessoa, mas, ao contrário do que possa parecer à primeira vista, esses documentos contêm ricas e variadas informações sobre múltiplos aspectos da vida" (FURTADO, 2009, p. 93). Partindo dessa premissa, nosso objetivo foi fazer ouvir essas duas vozes anônimas que jaziam nas folhas carcomidas pelo tempo, embora repletas de experiências vividas, e que podem ser inspiração para enfrentarmos as adversidades nossas de cada dia, sobretudo num momento em que, no Brasil, vivemos retrocessos políticos e sociais sem precedentes, de tal modo que autoridades governamentais negam evidências históricas do passado, como a existência do tráfico de escravizados e da própria escravidão; os direitos sociais das denominadas minorias de poder, duramente conquistados, estão sendo colocadas em xeque ${ }^{15}$. Nesse sentido, voltar às lutas do passado pode servir para iluminar as do presente.

\section{REFERÊNCIAS BIBLIOGRÁFICAS}

\section{Fontes primárias manuscritas}

Memorial da Justiça do Estado de Pernambuco. Comarca do Recife. Testamento de Rufina Maria da Conceição. Ano: 1869. Caixa: 1165.

Memorial da Justiça do Estado de Pernambuco. Comarca do Recife. Testamento de Bento da Costa. Ano: 1890. Caixa: 253.

Memorial da Justiça do Estado de Pernambuco. Comarcado Recife. Processo Cível (Ação de Liberdade). Caixa: 249. Ano: 1884.

\footnotetext{
${ }^{15}$ Estamos nos referindo às declarações do então candidato à presidência da República, eleito em 2018, e do ex-presidente da Fundação Palmares, do seu governo, acerca da escravidão e do tráfico de africanos para o Brasil. Trata-se de declarações divulgadas nos meios de comunicação social, sobretudo pela internet. Sobre tais afirmações, ver: Gonçalves (2018); Salgado; Dal Piva e Martinez (2018) e Portal R7 (2019).
}

Revista da ABPN • v. 12, n. Ed. Especial - Caderno Temático: "Africanos, escravizados, libertos biografias, imagens e experiências atlânticas” • agosto de 2020, p. 784-806 
Livros, dissertações, teses, monografias e revistas acadêmicas

BÍBLIA, N. T. Evangelho de Mateus. 22:21.

DEL PRIORE, Mary. História do Amor no Brasil. São Paulo: Contexto, 2005.

FAGE, J. D.; OLIVER, Roland. Breve História da África. 1. ed. Lisboa: Sá da Costa, 1980.

FURTADO, Júnia Ferreira. A morte como testemunho da vida. In: PINSKY, Carla Bassanezi; LUCA, Tânia Regina (Org.). O Historiador e suas fontes. São Paulo: Contexto, 2009.

LOPES, Nei. Enciclopédia Brasileira da Diáspora Africana. São Paulo: Selo Negro, 2004.

MOURA, Clóvis. Dicionário da Escravidão Negra no Brasil. São Paulo: Edusp, 2004.

QUINTÃO, Antonia Aparecida. Lá vem meu parente: As irmandades de pretos e pardos no Rio de Janeiro e em Pernambuco (Século XVIII). São Paulo: Annablume, 2002.

REGINALDO, Lucilene. “África em Portugal”: devoções, irmandades e escravidão no Reino de Portugal, século XVIII. História, São Paulo, v. 28, n. 1, 2009, p. 289-319.

REIS, João José. Identidade e diversidade étnica nas irmandades negras no tempo da escravidão. Revista Tempo, Rio de Janeiro, v. 2, n. 3, 1996, p. 7-33.

REIS, João José; GOMES, Flávio dos Santos; CARVALHO, Marcus J. M. de. O Alufá Rufino: tráfico, escravidão e liberdade no Atlântico Negro (1822-1853). São Paulo: Companhia das Letras, 2010.

SILVA, Alberto da Costa e. Francisco Félix de Souza, mercador de escravos. Rio de Janeiro: Nova Fronteira, UERJ, 2004.

SILVA, José Bento Rosa da. O Paraíso do Catimbó: Recife nas primeiras décadas do século XX. Revista da ABPN, v. 11, n. 29, jun.-ago. 2019, p. 174-197.

Jornais

A Província. Recife. 1890 a 1891.

A Província. Recife. 29/04/1890. Ed. 96.

A Província. Recife. 20/05/1890. Ed. 113.

Diario de Pernambuco. Recife. 17/04/1841. Ed. 107.

Diario de Pernambuco. Recife. 23/08/1843. Ed. 181.

Diario de Pernambuco. Recife. 28/08/1843. Ed. 184.

Diario de Pernambuco. Recife. 05/08/1844. Ed. 170.

Diario de Pernambuco. Recife. 15/08/1844. Ed. 180.

Revista da ABPN • v. 12, n. Ed. Especial - Caderno Temático: "Africanos,

escravizados, libertos biografias, imagens e experiências atlânticas” • agosto de 2020, 
Diario de Pernambuco. Recife. 17/04/1846. Ed. 107.

Diario de Pernambuco. Recife. 06/08/1846. Ed. 172.

Diario de Pernambuco. Recife. 01/04/1854. Ed. 75.

Diario de Pernambuco. Recife. 22/04/1863. Ed. 91.

Diario de Pernambuco. Recife. 14/01/1864. Ed. 10.

Diario de Pernambuco. Recife. 01/01/1865. Ed. 18.

Diario de Pernambuco. Recife. 16/02/1865. Ed. 38.

Diario de Pernambuco. Recife. 21/01/1867. Ed. 17.

Diario de Pernambuco. Recife. 29/08/1867. Ed. 197.

Diario de Pernambuco. Recife. 27/07/1869. Ed. 170.

Diario de Pernambuco. Recife. 29/07/1869. Ed. 172.

Diario de Pernambuco. Recife. 15/05/1889. Ed. 108.

Diario de Pernambuco. Recife. 17/04/1890. Ed. 86.

Diario de Pernambuco. Recife. 25/04/1890. Ed. 93.

Diario de Pernambuco. Recife. 23/08/1890. Ed. 191.

Diario de Pernambuco. Recife. 17/02/1891. Ed. 37.

Diario de Pernambuco. Recife. 17/09/1892. Ed. 210.

Diário Novo. Recife. 29/08/1844. Ed. 186.

Diário Novo. Recife. 03/12/1844. E. 264.

Diário Novo. Recife. 07/02/1846. Ed. 30.

Diário Novo. Recife. 23/02/1846. Ed. 43.

Diário Novo. Recife. 25/02/1846. Ed. 44.

Jornal do Recife. Recife. 26/08/1865. Ed. 197.

Jornal do Recife. Recife. 08/05/1866. Ed. 106.

Jornal do Recife. Recife. 11/05/1890. Ed. 57.

Revista da ABPN • v. 12, n. Ed. Especial - Caderno Temático: "Africanos, escravizados, libertos biografias, imagens e experiências atlânticas” • agosto de 2020, p. 784-806 
Jornal do Recife. Recife. 31/08/1890. Ed. 198.

Jornal O Liberal. Recife. 01/05/1869. Ed. 62.

O Constitucional. Recife. 21/08/1861. Ed. 122.

\section{Sites eletrônicos}

BRASIL. Poder Executivo do Império. Decreto No 1.331-A, de 17 de fevereiro de 1854. Approva o Regulamento para a reforma do ensino primario e secundario do Municipio da Côrte. Coleção de Leis do Império do Brasil (1854), vol. 1, pt I, p. 45 (publicação original). Disponível em: https://www2.camara.leg.br/legin/fed/decret/1824-1899/decreto-1331-a-17-fevereiro-1854590146-publicacaooriginal-115292-pe.html. Acesso em: 18/04/2020.

EMORY CENTER FOR DIGITAL SCHOLARSHIP. Explorar a dispersão de africanos escravizados pelo mundo atlântico. Disponível em: https://www.slavevoyages.org/. Acesso em: 17/04/2020.

GONÇALVES, Géssica Brandino. Portugueses nem pisaram na África, diz Bolsonaro sobre escravidão. Folha de S. Paulo. Publicado em: 31/07/2018. Disponível em: https://www1.folha.uol.com.br/poder/2018/07/portugueses-nem-pisaram-na-africa-diz-

bolsonaro.shtml. Acesso em: 17/04/2020.

GUILLEN, Isabel. Bairro do Recife: Rua da Senzala Velha. Projeto Memória da Escravidão e Cultura Negra em Pernambuco. Publicado em: 04/09/2017. Disponível em: https://memoriaescravidaope.wordpress.com/2017/09/04/rua-da-senzala-velha/. Acesso em: 17/04/2020.

PRESIDENTE da Fundação Palmares diz que escravidão foi 'benéfica'. Portal R7. Publicado em: 27/11/219. Disponível em: https://noticias.r7.com/brasil/presidente-da-fundacao-palmares-dizque-escravidao-foi-benefica-27112019. Acesso em: 17/04/2020.

SALGADO, Daniel; DAL PIVA, Juliana; MARTINEZ, Mariana. Bolsonaro na TV: 'Negar dívida com escravidão é apagar a História', diz historiadora. O Globo. Publicado em: 01/08/2018. Disponível em: https://oglobo.globo.com/brasil/bolsonaro-na-tv-negar-divida-com-escravidaoapagar-historia-diz-historiadora-22938430. Acesso em: 17/04/2020.

WIKIPÉDIA. Fora-de-Portas. Disponível em: https://pt.wikipedia.org/wiki/Fora-de-Portas. Acesso em: 17/04/2020.

WIKIPÉDIA. Pequena África. Disponível em: https://pt.wikipedia.org/wiki/Pequena_\%C3\%81frica. Acesso em: 17/04/2020.

Recebido em: 05/07/2020

Aceito em: $29 / 08 / 2020$

Revista da ABPN • v. 12, n. Ed. Especial - Caderno Temático: "Africanos,

escravizados, libertos biografias, imagens e experiências atlânticas" • agosto de 2020 , 